AGRICULTURE AND BIOLOGY JOURNAL OF NORTH AMERICA

ISSN Print: 2151-7517, ISSN Online: 2151-7525, doi:10.5251/abjna.2013.4.3.260.267

(C) 2013, ScienceHuß, http://www.scihub.org/ABJNA

\title{
Insecticidal and Antifeedant Efficacy of Jatropha oil extract against the Desert Locust, Schistocerca gregaria (Forskal) (Orthoptera: Acrididae)
}

\author{
Ebtisam M. Bashir ${ }^{1}$ and Hamadttu A.F. El Shafie ${ }^{2}$ \\ ${ }^{1}$ Department of plant protection and environmental studies, Faculty of Agriculture, Al-Zaiem \\ Al-Azhari University \\ ${ }^{2}$ Department of crop protection, Faculty of Agriculture, University of Khartoum, P.O. 13314, \\ Shambat, Sudan \\ Corresponding author's e-mail: elshafie62@yahoo.com \\ ABSTRACT
}

\begin{abstract}
Jatropha curcas (physic nut) is a drought-resistant multipurpose shrub or a small tree belonging to the Family Euphorbiaceae. Jatropha seed oil concentrations of $5 \%, 10 \%, 15 \%$ and $20 \%$ were tested for biological activity against the third nymphal instar of the desert locust, S. gregaria. All tested concentrations caused significant $(p<0.05)$ mortality in the experimental insects ranged from $22.4 \%$ to $59.2 \%$ after 7 days of application. The $\mathrm{LD}_{50}$ values for treated nymphs at 48,72 , and 96 hrs. were $3.12 \%, 6.57 \%$ and $9.85 \%$ respectively. Oil concentration of $10 \%$ has resulted in a delay of the development time from the $5^{\text {th }}$ to $6^{\text {th }}$ nymphal instar by 5 days, where treated nymphs had completed development in 16.50 days compared with only 11.33 days in the untreated control group and 12.00 days in the group treated with hexane. The same concentration (10\%) also significantly reduced the per cent of egg hatch. The concentration of $5 \%$ caused a significant, $50 \%$ more, antifeedant effect on the treated nymphs as compared to the untreated control group.
\end{abstract}

Keywords: Jatropha curcas, antifeedant effect, Schistocerca gregaria, mortality, nymphal instar.

\section{INTRODUCTION}

The desert locust Schistocerca gregaria (Forskal) has been a most serious crop pest in many countries of Africa and Asia (Steedman, 1990; Ceccato et al., 2007). During the 2003-200 desert locust campaigns and throughout the last invasion areas, control teams applied some 13 million liters of mainly organophosphorus pesticides to roughly 13 million ha of land (Lecoq, 2010). Current locust control operations are mainly based on organophosphorus pesticides as a result of the banning of organochlorine and especially dieldrin (Lecoq, 2001). Rembold (1994) adverted to the rapidly increasing insect tolerance against any type of neurotoxic insecticide, and all insecticides given their wide spectrum of action undoubtedly had substantial sideeffects on the non-target fauna (Müller, 1988). A preventive control strategy for locusts was developed as of 1960s and was recommended by FAO and applied by national and regional locust control units (FAO, 1968). The strategy requires monitoring ecological conditions and locust populations in outbreaks areas and conducting preventive treatments against the first gregarious locusts. Due to the regular application of this strategy, the frequency and duration of desert locust invasion were reduced since 1960s (Lecoq, et al., 1997). Peveling, et al. (1994) showed that, there was no evidence of serious side-effects of these alternative control agents on epigeal arthropods when compared with conventional insecticides. Mycopesticides, particularly Metarhizium anisopliae is the best solution to replace synthetic insecticides (Prior, 1992). This product acts slowly and is thus inappropriate for emergency situations. However, they should have a role in an integrated control strategy alongside classic insecticides (Lomeret al., 2001). It is now available on the locust control market and part of FAO (1999) list of products recommended for locust control. Other potential alternative is the pheromone phenylacetonitrile (PAN) which inhibits pheromonal communication among gregarious hoppers and induces stresses that lead to high mortality (Hassanali and Bashir, 1999). Various researches on the effect of botanical biopesticides including neem on desert locust have been or are being carried out as alternatives to the currently used harmful pesticides (Krall and Wilps, 1994). These botanicals are still at the experimental stage as far as locust control is concerned and large scale production is problematic and difficulties with the registration of variable products will limit adoption (Meinzingen and Kooyman 1997). The use of such 
products may be aimed at protecting crops locally (Lecoq 2001).

The Jatropha curcas (physic nut) is a droughtresistant multipurpose shrub or a small tree belonging to the Family Euphorbiaceae;it is a native of tropical America, but now thrives in many parts of the tropics and sub-tropics in Africa, Asia and southern America (Gübitzet al., 1999). The extracts of Jatropha showed nematicidal, fungicidal (Sharma and Trivedi 2002), antifeedant (Meshramet al. 1996), molluscicidal (Liu et al., 1997), and abortifacient activities (Goonasekaraet al., 1995) against white flies (B. tabaci), and exhibited insecticidal activities against moths, butterflies, aphids, bugs, beetles, flies, and cockroaches (Wink et al., 1997). Toxicity of $J$. curcas seeds is attributed to several components, including saponins, lectins (curcin), phytates, protease inhibitors, curcalonic acid and phorbol esters (Makkaret al., 1997).

The main objective of the present study was to evaluate the insecticidal and antifeedant efficacy of Jatropha oil against the desert locust Schistocerca gregaria, a phytophagous insect with great economic importance.

\section{MATERIALS AND METHODS}

Oil extraction: Fresh Jatropha curcas seeds were collected from EL.damazein rain-fed areas in the Blue Nile State, Sudan, where the plant is grown in large scale for the production of biofuel. The seeds were then cleaned, de-shelled and subsequently the kernels and hulls were separated manually. The kernels were dried, grounded to fine powder, and stored in glass vials until used.

To obtain the Jatropha oil, the powder (prepared as above) was defatted in a soxhlet apparatus using hexane $95 \%$ (boiling point $65-70{ }^{\circ} \mathrm{C}$ ). The hexane was removed using rotary evaporator apparatus at $80^{\circ} \mathrm{C}$. Extracted seed oil was transferred to a sample glass bottle and stored in the refrigerator for subsequent application.

Dilutions assayed: Jatropha oil was dissolved with hexane to obtain $5,10,15$ and $20 \%$ dilutions which were used for the bioassay test.Two groups of insects were used as control, one was sprayed with hexane only and the other was left untreated.

Insect rearing: Desert locust eggs were obtained from the International Centre of Insect Physiology and Ecology (ICIPE), Port Sudan and mass reared in the lath house of Crop Protection Department, University of Khartoum. Cages ( $1 \mathrm{~m} \times 1 \mathrm{~m} \times 0.35 \mathrm{~m})$ fitted with wire mesh and a movable window made of cloth, to facilitate cleaning and feeding, was used for the purpose. The cages stood on poles one meter from the ground, 24 cups $(10 \mathrm{~cm} \times 12 \mathrm{~cm})$ filled with moist soil were fitted in each cage for egg-laying. Locusts were fed on food plants such as Pennisetum typhoidium and Heliotropium spp in addition to wheat bran. The hatching nymphs were removed from the cups $(10 \mathrm{~cm} \times 12 \mathrm{~cm})$ to cages $(1 \mathrm{~m} \times 1 \mathrm{~m} \times 0.7 \mathrm{~m})$ fitted with cloth and wire mesh and supplied with food. The 3rd instar nymphs were used in all the trials. Some of nymphs were transferred into large cages $(4 \mathrm{~m} \times 2 \mathrm{~m} \times 2 \mathrm{~m})$ made from steel and wire mesh where they were kept for breeding and continuity of the colony.

Mortality and development duration of treated nymphs: For the bioassay, 180 third instar nymphs were divided into 6 groups (30 individuals each) and assigned for the six treatments as described above. The different concentrations were sprayed on the nymphs using a micron sprayer with the trade mark ULVA +. This ultra-low volume sprayer is designed primarily for the foliar application of insecticides and also for control of migrant pests like locusts and grasshoppers. The treated nymphs were allowed to dry for 2 minutes before being transferred into the experimental cages. Each cage measured $25 \mathrm{~cm} x$ $25 \mathrm{~cm} \times 25 \mathrm{~cm}$, with 4 faces covered with a wire mesh. One face was covered with cloth sleeve made in the form of a tube to facilitate cleaning, feeding and handling of treated insects. The bottom of the cage was covered by plywood. The number of dead insects was counted and surviving ones were carefully observed to determine the duration of development. Cast skins were used to determine the instars.

Antifeedant activity: The antifeedant effects of $10 \%$ Jatropha seeds oil against the third instar nymphs of $S$. gregaria were studied by mixing the Jatropha extract with $250 \mathrm{~g}$ of wheat bran. A $10 \%$ neem seed oil extract was included in the experiment for comparison. There were three replications and ten third instar nymphs were released in each replicate in an experimental cage. The wheat bran was provided to the nymphs in a Petri dish. Two sets of control were used, untreated wheat bran and bran mixed with hexane only. The unconsumed bran portions left in the dish were weighted at day 3 and day 6 after treatment and the amount of consumed food was estimated. The antifeedant index was calculated by the formula as adopted by Abivardi and Benz (1984). 


$$
\text { Antifeedant index }(A F I)=\frac{C-T}{C} \times 100
$$

Where:

$\mathrm{C}=$ Consumed wheat bran in control

$\mathrm{T}=$ Consumed wheat bran in treatment

Effect on egg hatchability: To study the effect of Jatropha oil on eggs produced by adult locusts treated in the third nymphal instars, 60 nymphs were used for the experiment. The insects were divided into two groups, 30 each. The first group was sprayed with Jatropha oil as described above, while the second group was left as control. Each group was introduced in a separate rearing cage and fed ad libitum upon seedlings of millet, Heliotropium spp., and wheat bran. The treated nymphs were followed until they reached the adult stage, where they were transferred to egg laying cage fitted with egg laying cups. The egg pods laid by each group were carefully observed for hatching and the per cent hatchability was calculated.

Statistical analysis: Treatments were arranged in a complete randomized design. Each treatment was replicated four times. Transformation of data was done using Arc Sine. Data were subjected to analysis of variance (ANOVA) and the means were separated using the least significant difference (LSD). The
Probit analysis was carried out to calculate regression equation (Finney, 1971), LT $\mathrm{LT}_{50}$, Lower fiducial limit, upper fiducial limit, time responses and Chi Square.

\section{RESULTS}

The biological activity of Jatropha oil on the 3rd nymphal instars of $S$. gregaria is shown in Fig.1. No significant mortality among nymphs could be observed after application among all treatments and control in the 2nd and 3rd day. However, from 4th to 7th day there was a significant difference between the different concentrations and control. As per statistical analysis, $20 \%$ oil treatment caused a significant percent mortality more than those of $5 \%$, $10 \%$ and $15 \%$. However, therewas no significant different between $10 \%$ and $15 \%$ after 7 days of exposure. These results indicated that $20 \%$ concentration level, gave the highest mortality $(59.2 \%)$ of the nymphs indicating that the efficacy of Jatropha oil against S. gregariais dose-dependent. Table1 and Fig 2 display the probit analysis responses of Jatropha oil on the 3rd instars nymph of S. gregaria after $48 \mathrm{hrs}$ of treatment. The test insects were sensitive to Jatropha oil as indicated by small $\mathrm{LD}_{50}$ value (3.12). The response was homogenous as indicated by narrower $L_{50} / L_{90}$ and slope. Responses after $72 \mathrm{hrs}$ are presented in table 2 and fig. 3.

Table 1. Log dose response of S. gregaria $3^{\text {rd }}$ instar exposed to Jatropha oil (48 hrs.)

\begin{tabular}{|c|c|c|c|c|c|c|c|c|}
\hline \multirow[t]{2}{*}{ Source } & \multirow{2}{*}{\multicolumn{2}{|c|}{ Lethal Dose\% }} & \multicolumn{2}{|c|}{ Fiducial limit } & \multirow{2}{*}{ Chi- squire } & \multirow{2}{*}{$\begin{array}{l}\mathrm{LD}_{90 \%} / \mathrm{LD}_{50 \%} \\
\text { ratio }\end{array}$} & \multirow{2}{*}{ Slope } & \multirow{2}{*}{ df } \\
\hline & & & lower & upper & & & & \\
\hline \multirow{3}{*}{ 48hrs } & $\mathrm{LD}_{10}$ & 0.72 & 0.21 & 1.15 & \multirow{3}{*}{0.047} & \multirow{3}{*}{4.31} & \multirow{3}{*}{1.14} & \multirow{3}{*}{1} \\
\hline & $\mathrm{LD}_{50}$ & 3.12 & 2.26 & 5.21 & & & & \\
\hline & $\mathrm{LD}_{90}$ & 13.45 & 7.09 & 80.09 & & & & \\
\hline
\end{tabular}

$\mathrm{LT}_{10}$ : lethal dose that kills $10 \%$ of the exposed nymphs $\mathrm{LT}_{50}$ : lethal dose that kills $50 \%$ of the exposed nymphs $\mathrm{LT}_{90}$ : lethal dose that kills $90 \%$ of the exposed nymphs df: degrees of freedom

Table 2: Log dose response of S. gregaria $3^{\text {rd }}$ instar exposed to Jatropha oil (72 hrs.)

\begin{tabular}{|c|c|c|c|c|c|c|c|c|}
\hline \multirow[t]{2}{*}{ Source } & \multirow{2}{*}{\multicolumn{2}{|c|}{ Lethal Dose\% }} & \multicolumn{2}{|c|}{ Fiducial limit } & \multirow{2}{*}{$\begin{array}{l}\text { Chi- } \\
\text { squire }\end{array}$} & \multirow{2}{*}{$\begin{array}{l}\mathrm{LD}_{90 \%} / \mathrm{LD}_{50 \%} \\
\text { ratio }\end{array}$} & \multirow{2}{*}{ Slope } & \multirow{2}{*}{$d f$} \\
\hline & & & lower & upper & & & & \\
\hline \multirow{3}{*}{72 hrs } & $\mathrm{LD}_{10}$ & 2.03 & 0.76 & 2.95 & \multirow{3}{*}{0.40} & \multirow{3}{*}{3.23} & \multirow{3}{*}{0.91} & \multirow{3}{*}{1} \\
\hline & $\mathrm{LD}_{50}$ & 6.57 & 5.90 & 10.00 & & & & \\
\hline & $\mathrm{LD}_{90}$ & 21.26 & 12.67 & 90.31 & & & & \\
\hline
\end{tabular}

$\mathrm{LT}_{10}$ : lethal dose that kills $10 \%$ of the exposed nymphs $\mathrm{LT}_{50}$ : lethal dose that kills $50 \%$ of the exposed nymphs $\mathrm{LT}_{90}$ : lethal dose that kills $90 \%$ of the exposed nymphs df: degrees of freedom 


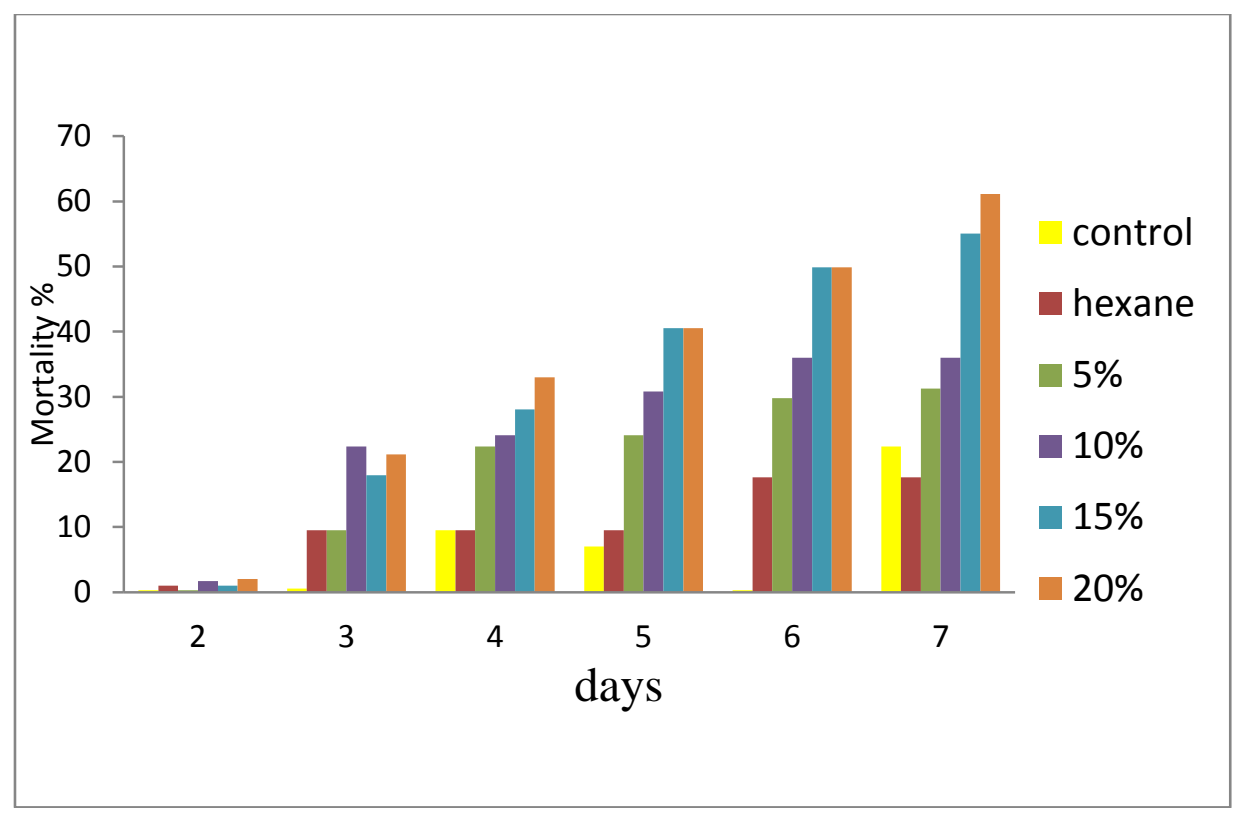

Fig. 1. Mortality percentage of different concentrations of Jatropha seed oil on the third nymphal instar of the Desert Locust, Schistocerca gregaria

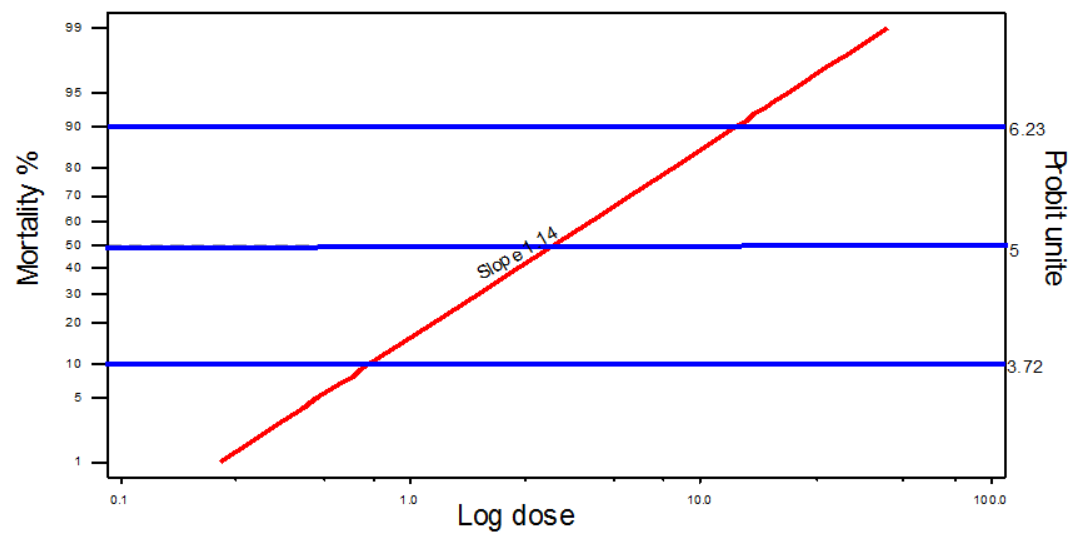

Fig.2. Log- dose mortality response of the third nymphal instar of S. gregaria, 48hrs after treatment with Jatropha seed oil.

The $\mathrm{LD}_{50}$ value was $6.57 \%$ as compared with $\mathrm{LD}_{50}$ of $9.85 \%$ achieved 96 hrs. after treatment.

Oil concentration of $10 \%$ has resulted in a delay of the development time from the $5^{\text {th }}$ to $6^{\text {th }}$ nymphal instar by 5days, where treated nymphs had completed development in 16.50 days compared with only 11.33 days in the untreated control group and 12.00 days in the group treated with hexane (Table 4). The same concentration also significantly reduced the per cent of egg hatch. Treated eggs showed hatchability per cent of $12.55 \%, 5.5 \%$ and $0.10 \%$ on the first, second and third days after treatment respectively (Table 5). The lowest oil concentration tested (5\%) caused a significant, $50 \%$ more, antifeedant effect on the treated nymphs as compared to the untreated control group. The percentage antifeedance of Jatropha oil was $72.64 \%$ and $78.92 \%$ at the day 3 and 6 after treatment respectively. The increase in antifeedant index with time indicated a long lasting effect of Jatropha oil (Table 6). 
Table 3: Log dose response of S. gregaria $3^{\text {rd }}$ instar nymphs exposed to Jatropha oil (96 hrs.)

\begin{tabular}{|c|c|c|c|c|c|c|c|c|}
\hline \multirow[t]{2}{*}{ Source } & \multirow{2}{*}{\multicolumn{2}{|c|}{ Lethal Dose\% }} & \multicolumn{2}{|c|}{ Fiducial limit } & \multirow{2}{*}{$\begin{array}{l}\text { Chi- } \\
\text { squire }\end{array}$} & \multirow{2}{*}{$\begin{array}{l}L_{90 \%} / L D_{50 \%} \\
\text { ratio }\end{array}$} & \multirow{2}{*}{ Slope } & \multirow{2}{*}{$\mathrm{df}$} \\
\hline & & & lower & upper & & & & \\
\hline \multirow{3}{*}{96 hrs } & $\mathrm{LD}_{10}$ & 1.79 & 0.43 & 3.08 & \multirow{3}{*}{0.19} & \multirow{3}{*}{5.49} & \multirow{3}{*}{1.32} & \multirow{3}{*}{1} \\
\hline & $\mathrm{LD}_{50}$ & 9.85 & 6.79 & 18.03 & & & & \\
\hline & $\mathrm{LD}_{90}$ & 54.15 & 25.61 & 43.39 & & & & \\
\hline
\end{tabular}

$\mathrm{LT}_{10}$ : lethal dose that kills $10 \%$ of the exposed nymphs

$\mathrm{LT}_{50}$ : lethal dose that kills $50 \%$ of the exposed nymphs

$\mathrm{LT}_{90}$ : lethal dose that kills $90 \%$ of the exposed nymphs

df: degrees of freedom

Table 4. The effect of Jatropha on nymphal development period of the desert locust, Schistocerca gregaria

\begin{tabular}{|l|l|l|l|}
\hline \multirow{2}{*}{ Treatment } & \multicolumn{3}{|c|}{ Duration (days) } \\
\cline { 2 - 4 } & $3^{\text {rd }}-4^{\text {th }}$ instar & $4^{\text {th }}-5^{\text {th }}$ instar & $5^{\text {th }}-6^{\text {th }}$ instar \\
\hline Control & $8.76 \mathrm{a}$ & $10.16 \mathrm{a}$ & $11.33 \mathrm{a}$ \\
\hline Hexane & $8.78 \mathrm{a}$ & $10.50 \mathrm{a}$ & $12.00 \mathrm{a}$ \\
\hline Jatropha oil (10\%) & $16.41 \mathrm{a}$ & $14.00 \mathrm{~b}$ & $16.50 \mathrm{c}$ \\
\hline LSD & 12.54 & 1.99 & 0.84 \\
\hline SE \pm & 6.89 & 1.09 & 0.45 \\
\hline
\end{tabular}

*Third instar nymphs were treated with Jatropha and their development was followed

The means followed by the same letter in the same column are not significantly different at $(P=0.05)$ according to LSD.

$\mathrm{LSD}=$ Least Significant Different

SE $\pm=$ Standard Error

Table 5. Per cent hatchability of eggs produced by S. gregaria treated in the third nymphal instar with Jatropha oil

\begin{tabular}{|l|l|l|l|}
\hline \multirow{2}{*}{ Treatment } & \multicolumn{2}{|c|}{ Days } \\
\cline { 2 - 4 } & 1 & 2 & 3 \\
\hline Control & $47.50 \mathrm{a}$ & $59.00 \mathrm{a}$ & $34.52 \mathrm{a}$ \\
\hline Jatropha oil 10\% & $12.55 \mathrm{~b}$ & $5.50 \mathrm{~b}$ & $0.10 \mathrm{~b}$ \\
\hline LSD & & & 13.74 \\
\hline SE \pm & 19.16 & 14.63 & 9.11 \\
\hline
\end{tabular}

The means followed by the same letter in the same column are not significantly different at $(P=0.05)$ according to LSD.

LSD = Least significant difference.

SE $\pm=$ Standard Error

Table 6. Percentage antifeedance of three botanical insecticides on the $3^{\text {rd }}$ nymphal instar of $S$. gregaria

\begin{tabular}{|l|c|c|}
\hline Treatment & After 3 days & After 6 days \\
\hline Untreated control & - & $(35.10) \mathrm{a}$ \\
\hline Control (hexane) & $(45.28) \mathrm{a}$ & $(79.62) \mathrm{b}$ \\
\hline Neem oil 5\% & $(76.45) \mathrm{b}$ & $(78.92) \mathrm{b}$ \\
\hline Jatropha oil 5\% & $(72.64) \mathrm{b}$ & 12.24 \\
\hline LSD & 14.59 & 6.73 \\
\hline SE \pm & 8.02 & \\
\hline
\end{tabular}

The means followed by the same letter (s) in the same column are not significantly different at (P=0.05) according to LSD.

LSD = Least Significant Different

$\mathrm{SE} \pm=$ Standard Error 


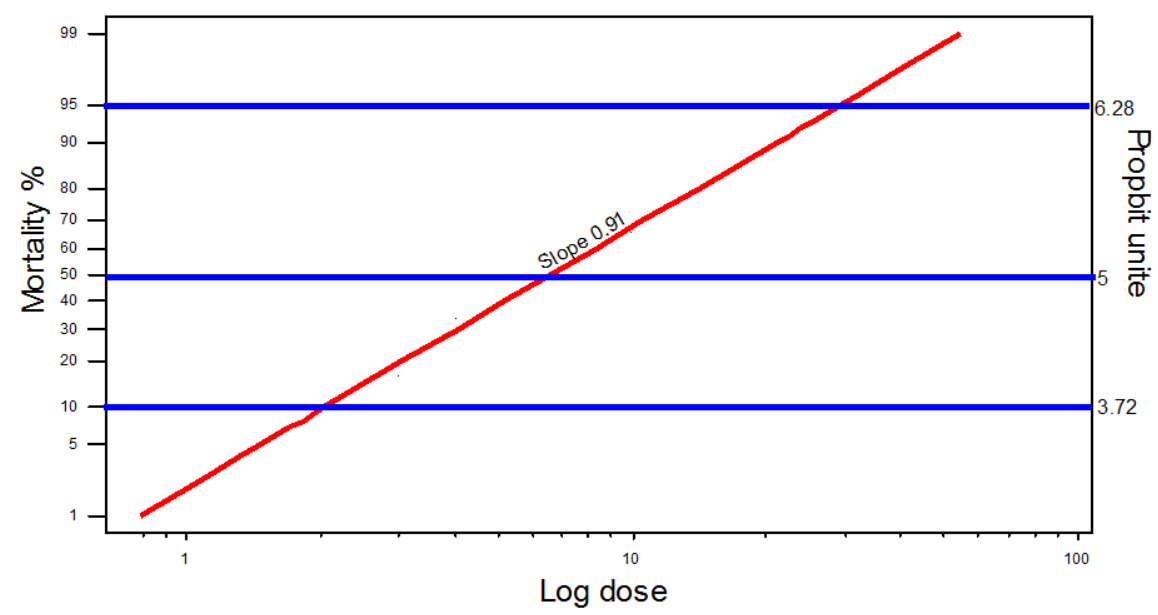

Fig. 3. Log dose response of $72 \mathrm{hrs}$ of third instar of $\mathrm{S}$. grgariatreated with jatropha seed oil.

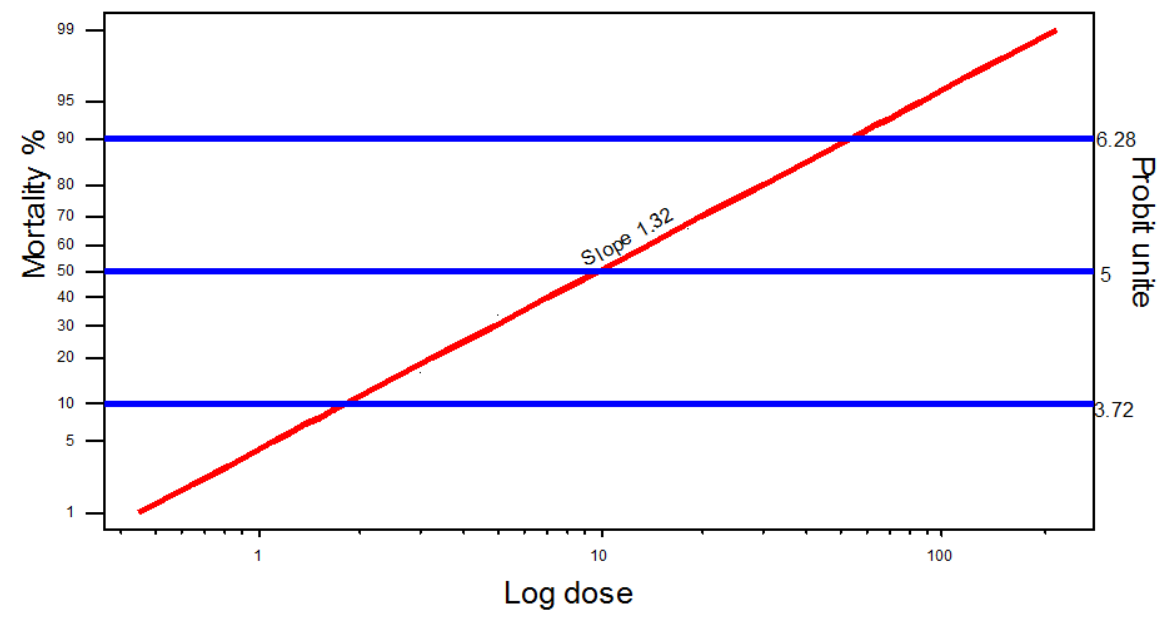

Fig. 4. Log dose response of $96 \mathrm{hrs}$ of third instar of S. gregaria treated with Jatropha seed oil.

\section{DISCUSSION}

Jatropha oil has shown insecticidal and antifeedant efficacy against a wide range of insects, sometimes the effect was comparable with synthetic insecticides. It was used to control maize weevil, Sitophilus zeamais in the field (Ohazurikeet al., 2003), Podagrica spp. On okra (Emosairue and Uguru, 1999), Spodoptera litura (Phowichit, et al., 2008), anti-oviposition and ovicidal effects on
Callosobruchus maculatus in cowpea (Adebowale and Adedire, 2006), Busseola fusca and Sesamia calamistis (Makharet al., 2007), Helicoverpa zea ( Aiyelaagbe and Gloer, 2008). The Jatropha oil also caused oviposition deterrence and inhibits hatching of eggs in potato tuber moth, Phthorimaea operculella (Shelkeet al., 1987). Jatropha oil when mixed with artificial diet inhibited growth of tobacco hornworm, Manduca sexta larvae (Sauerweinet al., 1993). 
The nymphal mortality was dose dependent and the effect of $J$. curcas oil did not manifest itself immediately after contact but occurred slowly within a week from the exposure. The $20 \%$ concentration proved to be toxic to $S$. gregaria. These results are in conformity with the work of Ogunleye, et.al (2010). According to their findings, the effects of jatropha oil on Sitophilus zeamais when applied at rate of $0.1 \mathrm{ml}$ and $0.2 \mathrm{ml}$ doses, after 12 hours of application produced mortality ranged from $50 \%-100 \%$ and $60 \%-100 \%$ respectively and cause $70 \%$ mortality for the application doses of $0.3 \mathrm{ml}$ and $0.4 \mathrm{ml}$ after $12 \mathrm{hrs}$. and reached $100 \%$ after $24 \mathrm{hr}$. Boateng and Kusi (2008) showed that the susceptibility of Jatropha seed oil to $C$. maculatus was highly toxic after72-hour exposure at all dosage $(0.5,1.0,1.5$ and $2.0 \mathrm{ml})$.

Probit analysis showed that Jatropha oil was more effective against desert locust as indicated by the low values of $L D_{90}$ and $L D_{50}$. The small value of Chisquire indicated accurate execution of experiments. The slopes were steep indicated homogenous population. Increase in concentrations increase the slope of regression line and caused progressive improvement of homogeneity.

Large number of published work concerning the effect of Jatropha oil on insects has not discussed the mechanism of action on the various insects studied. However, Jing et al. (2005) reported that Jatropherol1 , a diterpene, in vitro activated PKC of silkworm midgut cell (4.99- fold higher than that of control at $100 \mu \mathrm{g} / \mathrm{ml})$. He suggested that PKC was an important intracellular target of jatropherol-1 in insects, interfering with normal message transfer system in the mid-gut cell and producing a sequence of physiological/biochemical turbulence and finally resulting in death of the insect.

Singh and Sushilkumar (2008) reported a maximum wood protection of 60 days against Microcerotermes beesoni by using $20 \%$ jatropha oil. This persistency can be exploited for barrier treatment against hopper bands of the desert locust. The Jatropha oil can also be integrated with the pheromone phenylacetonitrile (PAN) for the integrated management of desert locust particularly in recession and before plague formation. However, field studies on evaluation of Jatropha toxicity to beneficial and non-target organisms are needed.

\section{REFERENCES}

Aiyelaagbe, O. O. and Gloer, J. B. 2008. Japodic acid, a novel aliphatic acid from Jatropha podagrica Hook. Rec. Nat. Prod. 2: 100-106.
Ceccato, P., Cressman, K., Giannini, A. and Trzaska, S. 2007. The desert locust upsurge in West Africa (20032005): Information on the desert locust early warning system and the prospects for seasonal climate forecasting. Int. J. Pest Management 53(1): 7-13

Devappa, R.K., Makhar, H. P. S. and Becker, K. 2010. Jatropha toxicity- A review. Journal of toxicology and environmental health, Part B. 13: 476-507.

Emosairue, S. O. and Uguru, E. I. 1999. Field trial of aqueous and petroleum ether extracts of Monodoramyristica (gaertn.) dural and Jatropha curcas L. for the control of okra flea beetle, Podagrica spp. J. Appl. Chem. Agric. Res. 6: 100-104.

FAO, 1968. Desert Locust project. Final report. Report No. FAO/SF: 34 DLC. Food and Agriculture organization of the United Nations, Rome

FAO, 1999. Evaluation of field trial data on the efficacy and selectivity of insecticides on locusts and grasshopper. Report to FAO by the pesticide referee group. Eight meeting. Rome, 11-14 October 1999. Food and Agriculture Organization of the United Nations, Rome.

Goonasekara MM, Gunawardhana VK, Jayaseana K, Mohammed SG, Balasubramaniam S (1995) Pregnancy terminating effect of Jatropha curcas in rats. J. Ethnopharmacol 47:117-123.

Gübitz, G.M., Mittelbach, M., Trabi, M., 1999.Exploitation of the tropical oil seed plant, Jatropha curcasL.Bioresource Technol.67, 73-82.

Hassanali, A. and Bashir, M. O. 1999. Insights for the management of different locust species from new findings on the chemical ecology of the Desert locust. Insects' science and its Application 19: 369-376.

Jing, L., Fang, Y., Ying, X., Wenxing, H., Meng, X., Syed, M. N. and Fang, C. 2005. Toxic impact of integrated jatropherol-I on selected enzymatic activities and ultrastructure of midgut cells in silkenworm, Bomboxymori L. J. Appl. Entomol. 129: 98-104.

Krall, S., Wilps, H. 1994. New trends in locust control. Deutsche Gesellschaftfür Technische Zusammenarbeit (GTZ) GmnH. Eschborn, Germany.

Lecoq, M. 2001. Recent progress in Desert and Migratory Locust management in Africa. Are preventive actions possible? Journal of Orthoptera Research 10, 277291.

Lecoq, M., Duranton, I.F., Rachadi, T. 1997. Towards an integrated strategy for the control of the desert locust. Pp. 467-473. In: Krall, S, Peveling R., Ba Diallo, D. (Eds.) New strategies in locust control. Birkhäuser, Basel, Switzerland.

Liu SQ, Shi JJ, Cao H, Jia FB, Liu XQ, Shi GL 2000. Survey of pesticidal component in Plant. In Entomology in China in 21st Century, Proceedings of 
2000 Conference of Chinese Entomological Society ed. Dianmo, Li Beijing, and China: Science \& Technique Press pp. 1098-1104.

Liu SY, Sporer F, Wink M, Jourdane J, Henning R Li YL, Ruppel, A. 1997. Anthraquinones in Rheum palmatum and Rumexdentatus (Polygonaceae), and phorbol esters in Jatropha curcas (Euphorbiaceae) with molluscicidal activity against the Schistosoma vector snails Oncomelania, Biomphalaria, and Bulinus. TM IH Trop. Med. Int. Health 2:179-188.

Lomer, C. and Langewald, J. 2001. What is the place of biological control in acridid integrated pest management? Journal of Orthoptera Research, 10, 335-341.

Makhar, H. P.S., Francis, G. and Beckar, K. 2007. Bioactivity of phytochemicals in some lesser known plants and their effects and potential applications in livestock and aquaculture production systems. Animal 1: 1371-1391.

Meinzingen, W., Kooyman, C. 1997. Results and recommendations of the working group Control agents and methods. Pp. 263-264. In: Krall, S, Peveling R., $\mathrm{Ba}$ Diallo, D. (Eds.) New strategies in locust control. Birkhäuser, Basel, Switzerland.

Meshram PB, Kulkarni N, Joshi K. C. 1996. Antifeedant activity of Azadirachta indica and Jatropha curcas against Papilio demoleus L. J Environ Biol 17:295-298.

Müller, P., 1988. Okotoxikologische Wirkungen von chlorierten Kohlenwasserstoffen, Phosphorsäureestern, Carbamaten und Pyrethroiden im nordöstlichen Sudan. Unpubl. Report to GTZ. Eschborn, Saarbrücken. 70 pp.

Ogunleye, R. F. Ogunkoya, M. OandAbulude, F. O., 2010. Effect of the seed oil of three botanicals, Jatropha curcas (L), Helianthus annus(L.) and Cocosnucifera(L) on the maize weevil, Sitophiluszeamais(Mots.)Plant Product Research Journal,14: 14 - 18.

Ohazurike, N. C., Omuh, M.O., and Emeribe, E.O. 2003. The use of seed extracts of physic nut (Jatropha curcas L.) in the control of maize weevil (Sitophiluszeamais M). Global J. Agric. Sci., 2: 86-88.

Peveling, R., Weyrich, J. and Müller, P. (1994) Side-effects of botanicals, insect growth regulators and entomopathogenic fungi on epigeal non-target arthropods in locust control In: New Trends in Locust Control (eds. S. Krall, H. Wilps), GTZ, Eschborn, TZVerlagsgesellschaft Rossdorf, p. 148-176.

Phowichit, S. Buatippawan, S. and Bullangpoti, V. 2008. Insecticidal activity of Jatropha gossypifolia L. (Euphorbiaceae) and Cleome viscosa L. (Capparidaceae) on Spodoptera litura (Lepidoptera: Noctuidae). Toxicity and carboxylesterase and glutathione- S- transferase activity studies. Commun. Agric. Appl. Biol. Sci. 73: 611-619.

Rembold, H. 1994. Controlling locusts with plant chemicals In: New Trends in Locust Control (eds. S. Krall, H. Wilps), GTZ, Eschborn, TZVerlagsgesellschaft Rossdorf, p. 41-49.

Sauerwein, M., Sporer, F. and Wink, M. 1993. Insecttoxicity of phorbol esters from Jatropha curcas seed oil. Planta Med. 59: A686.

Sharma N, Trivedi PC (2002) Screening of leaf extracts of some plants for their nematicidal and fungicidal properties against Meloidogyne incognita and Fusarium oxysporum. Asian J Exp. Sci. 16:21-28.

Shelke, S. S., Jadhav, L.D. and Salunkhe, G. N. 1987. Ovicidal action of some vegetable oils and extracts on the storage pest of potato, Phthorimaea operculella Zell. Biovigyanam 13: 40-41.

Singh, N. and Sushilkumar. 2008. Anti-termite activity of Jatropha curcas L. biochemicals. J. Appl. Sci. Environ. Manage. 12 (3): 67-69.

Steedman, A., (ed.) (1990). Locust Handbook, Natural Resources Institute, Chatham, U. K.

Wink M, Koschmieder C, Sauerwein M, Sporer, F. 1997. Phorbol esters of Jatropha curcas-biological activities and potential applications. In: Gübitz GM, Mittelbach M, Trabi M (eds) Biofuel and industrial products from Jatropha curcas. Dbv- Verlag Univ., Graz. 